\title{
Hard Metal Particles and Lung Disease: Coincidence or Causality?
}

\author{
H.W. Ruediger \\ Department of Occupational Medicine, University of Vienna, Austria
}

Hard metal is essentially produced by heating tungsten carbide together with cobalt powder at about $1,500^{\circ} \mathrm{C}$. The resultant product consists of about $80 \%$ tungsten carbide, $10-20 \%$ cobalt, and may also contain minor amounts of other metals, frequently titanium. The combination of tungsten carbide with cobalt may - obviously in a synergistic way [1] - induce a particular lung disease, which has been described in workers exposed to hard metal dust [2] and in laboratory animals [3]. The development of hard metal lung disease (HMLD) is a rare event and is almost unrelated to the duration and extent of exposure, an observation which has been attributed to the presence of a particular individual sensitivity [4]. An autoimmune mechanism has been suspected. HMLD is clinically characterized largely by a restrictive lung disease with reduced diffusion capacity due to alveolitis with progression to fibrosis. The prognosis is rather poor [5], and progression after cessation of exposure is frequent. In most cases steroid therapy was attempted with minor effects only [6]. Histologically tungsten carbide particles can be demonstrated in the macrophages and fibrotic tissue, whereas cobalt cannot be found in most cases due to rapid clearance from lung tissue [6]. When HLMD is suspected because of occupational exposure, alveolitis and lung fibrosis, the diagnosis is further supported by demonstration of tungsten carbide particles in lung tissue or $\mathrm{BAL}$, and it is ascertained by the histologic demonstration

\begin{tabular}{ll}
\hline KARGER & ( 2000 S. Karger AG, Basel \\
0025-7931/00/0672-0137\$17.50/0 \\
$\begin{array}{l}\text { Fax +4161306 1234 } \\
\begin{array}{l}\text { E-Mail karger@karger.ch } \\
\text { www.karger.com }\end{array}\end{array}$ & $\begin{array}{l}\text { Accessible online at: } \\
\text { www.karger.com/journals/res }\end{array}$
\end{tabular}

of pathognomonic multinuclear giant cells in the alveolar space [7-9].

In this issue of Respiration Hahtola et al. [10] describe a 45-year-old female hard metal worker with alveolitis and lung fibrosis and tungsten carbide particles in her lung tissue. Histologically, however, the lung biopsy showed a pattern suggestive of sarcoidosis with epitheloid cell granuloma. Multinucleated giant cells are not described. Consistent with sarcoidosis rather than HMLD are enlarged hilar lymph nodes, the development of arthralgia, and a rapid clinical improvement when therapy with steroids was initiated. In fact, sarcoidosis must always be considered as an alternative diagnosis to HMLD [11]. The authors discuss the resemblance of the clinical, radiological, and histological findings with sarcoidosis, but the title of their article suggests that HMLD is proven in this case. This diagnosis, however, is solely based on the demonstration of tungsten carbide particles in the patient's lung, being a consequence of working at a grinding machine for 5 years. Therefore the hard metal dust particles in the patient's lung do not mean that hard metal dust is causal to her disease, in particular when the latter is atypical for HMLD. A lot of foreign material is deposited in the lungs. It can be used as an indicator of exposure, but not as an indicator of disease. If this were not the case, then the sole presence of asbestos bodies in the patient's lungs would prompt a diagnosis of 'atypical

\footnotetext{
o.Univ. Prof. Dr. H.W. Ruediger

Department of Occupational Medicine

University of Vienna, Währinger Gürtel 18-20

A-1090 Vienna (Austria)
}

Tel. +431 40400 4700, Fax +4314088011 
asbestosis', the presence of birefringent bodies 'atypical silicosis', and so on.

Even novel occupational diseases can be generated in this way. An example may be 'toner lung' [12] which has been desribed in a case of transitory granulomatous pneumonitis and mediastinal lymphadenopathy in a 40-year- old male who was employed as a service man for photocopy machines and was occasionally exposed to toner dust. This prompted the authors to assume a causal relationship between exposure to toner dust and the lung disease, which otherwise would certainly have been considered as sarcoidosis. Coincidence does not mean causality.

\section{References}

1 Lison D, Lauwerys R: Cobalt bioavailability from hard metal particles. Further evidence that cobalt alone is not responsible for the toxicity of hard metal particles. Arch Toxicol 1994;68:528-531.

2 Balmes JR: Respiratory effects of hard-metal dust exposure. Occup Med 1987;2:327-344.

3 Lison D: Human toxicity of cobalt-containing dust and experimental studies on the mechanism of interstitial lung disease (hard metal disease). Crit Rev Toxicol 1996;26:585-616.

4 Potoliccio I, Mosconi G, Forni A, Nemery B, Seghizzi P, Sorrentino R: Susceptibility to hard metal lung disease is strongly associated with the presence of glutamate 69 in HLA-DP beta chain. Eur J Immunol 1997;27:2741-2743.
5 Frost AE, Keller CA, Brown RW, Noon GP, Short HD, Abraham JL, Pacinda S, Cagle PT: Giant cell interstitial pneumonitis. Disease recurrence in the transplanted lung. Am Rev Respir Dis 1993;148:1401-1404.

6 Ruokonen EL, Linnainmaa M, Seuri M, Juhakoski P, Soderstrom KO: A fatal case of hardmetal disease. Scand J Work Environ Health 1996;22:62-65.

7 Abraham JL, Burnett BR, Hunt A: Development and use of a pneumoconiosis database of human pulmonary inorganic particulate burden in over 400 lungs. Scanning Microsc 1991; 5:95-104.

8 Ohori NP, Sciurba FC, Owens GR, Hodgson MJ, Yousem SA: Giant-cell interstitial pneumonia and hard-metal pneumoconiosis. A clinicopathologic study of four cases and review of the literature. Am J Surg Pathol 1989;13:581587.
9 Auchincloss JH, Abraham JL, Gilbert R, Lax M, Henneberger PK, Heitzman ER, Peppi DJ: Health hazard of poorly regulated exposure during manufacture of cemented tungsten carbides and cobalt. Br J Ind Med 1992;49:832836.

10 Hahtola PA, Järvenpää RE, Lounatmaa K, Mattila JJ, Rantala I, Uitti JA, Sutinen S: Hard metal alveolitis accompanied by rheumatoid arthritis. Respiration 2000;67:209-212.

11 Rizzato G, Fraioli P, Sabbioni E, Pietra R, Marberis M: Multi-element follow up in biological specimens of hard metal pneumoconiosis. Sarcoidosis 1992;9:104-117.

12 Armbruster C, Dekan G, Hovorka A: Granulomatous pneumonitis and mediastinal lymphadenopathy due to photocopier toner dust. Lancet 1996;348:690. 